Article

\title{
Tourists' Environmentally Responsible Behavior in Response to Climate Change and Tourist Experiences in Nature-Based Tourism
}

\author{
Ju Hyoung Han ${ }^{1}$, Min Jae Lee ${ }^{2, *}$ and Yun-Seop Hwang ${ }^{3}$ \\ 1 College of Hotel and Tourism Management, Kyung Hee University, 26, Kyungheedae-ro, Dongdaemun-gu, \\ Seoul 02447, Korea; juhyounghan@gmail.com \\ 2 Research Institute of Social Science, Kyung Hee University, 26, Kyungheedae-ro, Dongdaemun-gu, \\ Seoul 02447, Korea \\ 3 Department of International Business \& Trade, Kyung Hee University, 26, Kyungheedae-ro, \\ Dongdaemun-gu, Seoul 02447, Korea; rusiahys@khu.ac.kr \\ * Correspondence: sophie@khu.ac.kr; Tel.: +82-10-9652-7680 \\ Academic Editor: Ian Patterson \\ Received: 30 May 2016; Accepted: 4 July 2016; Published: 8 July 2016
}

\begin{abstract}
Nature-based tourism destinations-locations in which economic viability and environmental responsibility are sought—are sensitive to climate change and its effects on important environmental components of the tourism areas. To meet the dual roles, it is important for destination marketers and resources managers to provide quality experiences for tourists and to induce tourists' environmentally responsible behavior in such destinations. This study documents the importance of perceptions toward climate change and tourist experiences in determining tourists' environmentally responsible behavior while enjoying holidays at nature-based tourism destinations in Jeju Island, South Korea. Two hundred and eleven Korean and 204 Chinese tourists marked dominant tourist arrivals to the island, and responded to the survey questionnaire. Results showed that perceptions toward climate change and tourist experiences affect Korean tourists' environmentally responsible behavior intentions, whereas tourist experiences—not perceptions toward climate change-only significantly affect Chinese tourists' behavior intention. In a nature-based tourism context under the pressure of climate change and adverse environmental effects as consequences of tourism activities, resources managers and destination marketers need to develop environmental campaigns or informative tourist programs to formulate environmentally responsible behavior as well as to increase tourist quality experiences among domestic and international tourists.
\end{abstract}

Keywords: environmentally responsible behavior; climate change; tourist experience; nature-based tourism; domestic and international tourists

\section{Introduction}

Global societies have been acknowledging the issues surrounding climate change and $\mathrm{CO}_{2}$ emissions, and have developed international agreements such as the Kyoto Protocol and the UN Framework Convention on Climate Change [1]. There have been various attempts to adapt to such unavoidable impacts of climate change and prevent more detrimental impacts through the reduction of emissions [2]. Tourism has also been connected to the rising interests in the global phenomena of climate change, as the UNWTO (United Nations World Tourism Organization) organized the First Conference on Climate Change and Tourism in 2003 [3]. Since then, there have been discussions about the role of tourism as a net contributor to global greenhouse gas emissions, and the UNTWO Davos Declaration encourages tourists to reduce their carbon footprints or offset their emissions, and to opt 
for environmentally friendly activities that contribute to the preservation of the natural environment and consider the economic, societal and environmental impacts of their travel behavior [4].

On the one hand, although tourists are aware of climate change, they would not be willing to change their behavior through reducing air travel, among other ways, to reduce their personal carbon footprint $[5,6]$. On the other hand, tourists would adopt the necessary behavior to minimize the dangers posed by climate change if they were aware of climate change and its consequences [1,7]. Specifically, climate change could affect tourist perceptions about weather conditions, safety, attractiveness and seasonality of the destination [7], which is associated with travel experience [8]. Accordingly, we can assume that when tourists become more aware of and concerned about climate change or its impacts, they are more likely to behave in environmentally responsible ways. Researchers have held ongoing discussions on the associations between perceptions toward climate change and environmentally responsible behavior, but the effects of perceptions toward climate change on tourists and environmental behavior are not yet conclusive.

Nature-based tourism destinations seek opportunities to increase the local economy by utilizing their resources to attract more tourist arrivals, yet adverse environmental impacts may occur if tourism grows and tourists behave in inappropriate ways while traveling $[9,10]$. It is challenging in nature-based tourism destinations to balance economic viability and environmental responsibility. To meet the dual roles, it is important for destination marketers and resources managers to provide quality experiences for tourists and to induce tourists' environmentally responsible behavior in destinations [11]. Under the pressure of climate change and adverse environmental effects as consequences of tourism activities, there has been increasing interest in the study of tourists' on-site experiences and environmentally responsible behavior, e.g., References [10-13].

Understanding tourists' environmentally responsible behavior while traveling is critical to nature-based tourism destinations when they expect both economic and environmental sustainability. Researchers addressed that tourists are likely to behave in environmentally responsible ways when they are exposed to the natural environment and participate in nature-based on-site experiences $[10,14]$. Specifically, researchers explained that the connection with natural environments encourages nature-based tourists' environmentally responsible behavior by strengthening the tourists' environmental knowledge and environmental attitudes [10,15]. Thus, it is logical to expect that those tourists with quality experiences in a nature-based tourism destination and strong concerns for the environment are more likely to behave in an environmentally responsible way at a destination. However, little is known about whether and how such tourist experiences (i.e., increased perceived value and satisfaction) and perceptions toward climate change (i.e., awareness and moral responsibility) affect the likelihood of tourists' engagement in environmentally responsible behavior while traveling.

Furthermore, despite the fact that international tourism is rapidly growing worldwide, not many comparative studies have been done. A comparative study of two (or more) tourist groups from different countries can provide useful information to better understand tourists' environmentally responsible behavior in nature-based tourism destinations that attract international tourists.

The purpose of this study is to examine the differences of perceptions toward climate change, tourists' experiences, and tourists' environmentally responsible behavior between domestic (i.e., Korean) and international (i.e., Chinese tourists in this study) tourists at Jeju Island, South Korea. Two tourist groups are recognized in this research as these groups are the most dominant tourist groups on this island. This study also assesses the effects of perceptions toward climate change and tourist experiences on nature-based tourists' environmentally responsible behavior and compares the associations between domestic and international tourists. The specific objectives are: (1) to examine and compare the perceptions toward climate change (i.e., awareness and moral responsibility) and the tourist experiences (i.e., perceived value and satisfaction) between Korean and Chinese tourists; (2) to examine the effects of perception toward climate change and tourist experiences on nature-based tourists' environmentally responsible behavior; and (3) to compare the relationships between determinants and environmentally responsible behavior between Korean 
and Chinese tourists. It is expected that this study's findings will suggest strategies for resource managers and destination marketers to reduce the negative environmental impacts of climate change at a nature-based tourism destination by assessing and comparing determinants of domestic and international tourists' environmentally responsible behavior while traveling.

\section{Literature Review}

\subsection{Climate Change and Tourism}

Tourism is both a potential victim of as well as a significant contributor to climate change $[6,16]$. Tourism can be a threatened by predicted changes in the global climate [1,17]. Previous research has discussed the diverse impacts of climate change on tourism including tourism demand $[18,19]$, destination choice [20,21], and seasonality [22]. Recent research has identified the potential negative impacts of climate change on environmental and tourism-dependent economic long-term sustainability in climate change-sensitive regions [23] such as coastal areas [24], winter sports regions [25,26], and coral reefs $[6,27,28]$. Every destination is climate-sensitive to some extent [29]. For example, researchers address that global warming could lead to the decline of traditional resorts in certain locations as they expect the attractiveness of destinations would be gradually shifted towards higher latitudes and altitudes [30]. Researchers also pointed out that less than half of the existing ski resorts would be sustained within a few decades in Switzerland [25]. Also, a number of studies addressed the critical impacts of climate change on beach/island tourism destinations [28,31,32].

Literature has addressed the potential impacts of climate change on tourism destinations and industry as described above, yet perspectives on how tourism activities and tourist behavior impact climate change have been relatively limited, with only a few studies focusing on energy use and greenhouse gas emissions, e.g., References [33,34]. As a most frequently discussed issue, the rapid expansion of air travel and aviation fuel may have significant contributions to climate change [35,36]. However, on-site tourism activities can also be an accelerator of climate change [1,37]. Tourism development such as beach-front hotels can increase beach erosion, which accelerates the effects of rising sea levels and climate change [37]. Also, research has examined the role of tour operators in order to reduce greenhouse gas emissions from marine tours [28].

The controversy regarding the impact of tourism on the global climate has been discussed in the literature, with concerns about scientific uncertainty [38]. Discussions about the impacts of tourism on climate change need to be done further with long-term and international-scale scientific measurements. However, it has been observed that certain tourism activities affect natural environments on a local scale, which would exacerbate impacts on climate change [37] such as erosion, sedimentation, pollution, overfishing, and habitat alterations [39]. Tourism activities with less human-induced stresses to wildlife habitats and limited tourist footprints in natural environments would help local ecosystems to cope with climate change, if we cannot say tourism activities have direct impacts on climate change [40]. For example, the capacity of sandy beaches to cope with rising sea levels and the likely consequent increases in erosion would be managed well by local activities such as limiting tourist access, and implementing coastal resource conservation or environment education programs [41].

Despite previous studies' attempts to assess the relationships between climate change and tourism, few studies have examined tourists' environmentally responsible behavior in response to climate change, and tourist experiences in nature-based tourism contexts. Accordingly, this study measures tourists' perceptions toward climate change and tourists' experiences, and examines how these determinants affect tourists' environmentally responsible behavior among nature-based tourists.

\subsection{Environmentally Responsible Behavior}

Environmentally responsible behavior can be defined as: "the extent to which it changes the availability of materials or energy from the environment or alters the structure and dynamics of ecosystems or the biosphere" [42] (p. 408). Researchers agree that if individuals behave in 
environmentally responsible ways, economic and environmental sustainability in nature-based tourism destinations would be achieved more effectively [12,43]. Nature-based destinations such as wildlife habitats, coral reefs, and sandy beaches provide tourists with various opportunities for recreational experiences, environmental education, and entertainment $[9,11]$. The quality of the environment is threatened by problems such as global warming, pollution, the fast decline of forests and desertification, and the growing number of arrivals of tourists demonstrating inappropriate behavior. This has led to increasing calls to promote environmentally sustainable practices in nature-based tourism destinations [44].

Researchers discussed different categories of environmentally responsible behaviors such as recycling, energy-saving, green consumption (e.g., buying eco-products), and political action (e.g., voting for a public official who is concerned with environmental issues) [45,46]. From a tourism perspective [47], conceptualized tourists' environmentally responsible behavior includes conserving the natural environment and reducing the interference of the local environment, voluntarily visiting a destination less or not at all while the area needs to recover because of environmental damage, and taking actions to reduce the damage to a specific destination. Tourism researchers operationalized environmentally responsible behavior differently depending on study contexts, e.g., References $[11,48]$.

Tourists may not be aware that their behavior would harm ecosystems while traveling [49]. Therefore, it is important to cultivate tourists' environmentally responsible behavior in order to minimize negative impacts on ecosystems, and to avoid environmental degradation in nature-based tourism destinations, while providing quality tourist experiences. Researchers have identified different approaches to minimizing the negative environmental impacts of tourism, including planning and regulations [49] and more rigorous legislation enforcement [50]. Other literature has also discussed that voluntary environmental behavior among tourists needs to be seen as an important contributor to the solutions [13].

To identify determinants of tourists' environmentally responsible behavior in nature-based tourism destinations, this study includes two important factors: (1) perceptions toward climate change (i.e., awareness and moral responsibility) and (2) tourists' experiences (i.e., perceived value and satisfaction). The following sections describe these two factors.

\subsection{Perceptions toward Climate Change}

Climate change can be defined as the "statistical distribution of weather patterns when that change lasts for an extended period of time" [51] and is usually observed by the change in average weather conditions such as temperature, hot waves and precipitation, or variation of weather represented by extreme weather events. Climate change can be measured by observations on weather conditions and explained by scientific data. At the same time, researchers in the social sciences attempted to assess the perception of human beings on climate change, which is beneficial to understanding the relationship between climate change and related human behaviors, e.g., References [52,53]. For example, the authors of [52] measured the perceptions on climate change of the New Zealand public and assessed the relationship between their perceptions and mitigated actions. The authors of [54] examined the perceived risks of climate change affecting attitudes towards climate change policies.

Variables and measurement items to assess individuals' perceptions toward climate change have varied depending on the context of the studies and the authors' viewpoints. Moreover, commonly used variables and items are absent. Therefore, to measure the perceptions toward climate change and to assess its effects on environmentally responsible behavior, this study adapts two theoretical constructs-i.e., awareness and moral responsibility-from the theory explaining environmentally responsible behavior. The Value-Belief-Norm (VBN) theory illustrated that awareness of and responsibility for environmental consequences are important elements that induce environmentally responsible behavior [42]. Empirical research supported that higher environmental awareness and higher personal moral responsibility affect tourists' environmentally responsible behavior, 
e.g., Reference [55]. From the studies above, it is expected that awareness of and responsibility for climate change affect nature-based tourists' environmentally responsible behavior at destinations.

However, there are still controversies regarding the effectiveness of environment-related perceptions in explaining environmental behavior $[1,56]$. Researchers agree that environmental awareness can be very limited in explaining environmental behaviors. For example, the authors of [57] showed that there exists no difference in environmental knowledge levels between environmentalist and non-environmentalist groups. This argument is further strengthened by the study in [56] showing that at least $80 \%$ of the motives of environmental behavior would be situational or caused by other internal factors. This implies that environmental knowledge or awareness per se may not be a prerequisite for environmentally responsible behavior.

To date, researchers have found controversial results, and the ways in which the perceptions toward climate change impact environmentally responsible behavior have not been examined in nature-based tourism destinations which invite international tourists. Also, perceptions toward climate change differ across different nations [58]. According to [59], which compiled all the relevant surveys and studies on the public opinion about climate change with a cross-national viewpoint, public familiarity with, knowledge about and anthropogenic sources of climate change, and public support for energy alternatives and conservation differ across nations across the globe. For example, the Chinese were the least concerned with climate change, but they were the most supportive of policy alternatives to solve the problems. To fill this gap, this study examines and compares the effects of perceptions toward climate change on environmentally responsible behavior between domestic Korean and international Chinese tourists.

\subsection{Tourist-Perceived Value and Satisfaction}

Tourist-perceived value and satisfaction are important components in tourists' experiences as they are used as measures of success or failure of tourism to deliver a high quality traveling experience [60]. Among other measures of tourist experiences, perceived value and satisfaction are also comprehensive constructs. Perceived value encompasses the overall evaluation of multi-dimensional travel experience aspects such as quality, price, and emotional factors [61]. Satisfaction is also reflective of both evaluative judgment and affective feeling [62]. Such tourist experiences with increased perceived value and satisfaction are considered further determinants of environmentally responsible behavior [43,48,63], suggesting that benefits from a high quality experience may result in additional support for a protected area, thus accelerating interest in conservation.

From the perspective of the educational roles of nature-based tourism activities, researchers see that on-site recreation experiences would improve individuals' environmentally responsible behavior $[9,14,15]$. Tourists' enjoyable experiences, which expose them to the natural environment while traveling, may improve their understanding of or attitude towards nature, which may increase environmentally responsible behavior $[14,15]$. Researchers have suggested that on-site experiences at nature-based tourism destinations provide opportunities for tourists to make contact with wildlife, and have the potential to change (or access) their behavior [9].

Others, however, offer an alternative explanation. Scholars argue that increased personal benefits induce less engagement in environmentally responsible behavior. For example, [1] suggested that there would be negative associations between the benefits of environmental behavior and individuals' perceived environmental risks. That is, if individuals see personal benefits to be larger, the negative environmental impacts caused by actions are perceived less. In contrast, when personal benefits are seen as being limited to themselves, or the benefits are associated with others, individuals are likely to perceive behavior-induced negative environmental impacts as being large. For example, as [1] further illustrated, people perceive pollution from a vehicle to be less severe because of the considerable personal benefits associated with driving. In the same manner, because of the high personal benefits associated with leisure travel, its negative environmental impacts would be perceived less, which in turn induces less engagement in environmentally responsible behavior. 
To address this inconclusive discussion, this study examines how tourist-perceived value as well as satisfaction are associated with and related to nature-based tourists' environmentally responsible behavior. This study proposes that through a quality experience, tourists may develop an increased perceived value of their travel experience and a higher level of satisfaction with their recreational experience, both of which ultimately affect tourists' environmentally responsible behavior at a nature-based tourism destination. Also, the manner in which tourists' perceived value and satisfaction influence environmentally responsible behavior would differ between the two different tourist groups.

\section{Methodology}

\subsection{Sampling}

The population of this study consists of Korean and Chinese tourists who visited nature-based destinations in Jeju Island in Korea. In order to effectively measure the perceptions of tourists, a self-administered survey was conducted. Jeju Island is Korea's first property to be designated as a World Natural Heritage site titled 'Jeju Volcanic Island and Lava Tubes', which includes Mt. Halla Natural Reserve, Seongsan Ilchulbong Tuff Cone and Geomunoreum Lava Tube System. Mt. Halla was also appointed as the core area of the UNESCO Biosphere Reserve, and Seongsan Ilchulbong Tuff Cone is the top destination in Jeju Island according to the number of tourists. Jeju Island is a popular destination for domestic as well as international tourists. Among international tourists, Chinese tourists especially accounted for the majority of the inbound market. In 2014, the Chinese account for 2.91 million (88\%) of the 3.32 million international tourists to Jeju Island [64].

With all of these facts considered, questionnaires were administered to both Korean and Chinese tourists at two nature-based destinations-Mt. Halla and Seongsan Ilchulbong Tuff Cone-in February 2014. Convenient sampling was used, which a method to collect data from a population that is conveniently available to participate in survey. At the two research sites, eight trained research assistants asked respondents to complete the questionnaire. Tourists who were willing to participate in the study voluntarily completed the self-administered questionnaire. A small gift was given to the respondents who finished the questionnaire. A total of 420 questionnaires were completed-286 from Seongsan Ilchulbong Tuff Cone and 134 from Mt. Halla-and 415 valid responses were used in further analyses. Final samples included 211 Korean (50.8\%) and 204 Chinese (49.2\%) surveys. A total of $63.1 \%$ in this sample are female (63.1\%) and $57.8 \%$ are aged below 40 . More than a half (59\%) earn between 2 and 6 million Korean Won a month, and $68.2 \%$ of the respondents were accompanied family members or friends. The characteristics of respondents are presented in Table 1.

Table 1. The characteristics of the respondents.

\begin{tabular}{|c|c|c|c|c|c|c|c|}
\hline & \multicolumn{3}{|c|}{ Number of Respondents } & & \multicolumn{3}{|c|}{ Number of Respondents } \\
\hline & Korean & Chinese & Total (\%) & & Korean & Chinese & Total (\%) \\
\hline \multicolumn{4}{|c|}{ Gender } & \multicolumn{4}{|c|}{ Accompanying persons } \\
\hline Male & 106 & 47 & $153(36.9 \%)$ & None & 8 & 33 & $41(9.9 \%)$ \\
\hline Female & 105 & 157 & $262(63.1 \%)$ & Couple & 20 & 24 & $44(10.6 \%)$ \\
\hline Age & & & & Family & 107 & 61 & $168(40.5 \%)$ \\
\hline Below 30 & 93 & 18 & $111(26.7 \%)$ & Friends & 52 & 63 & $115(27.7 \%)$ \\
\hline $30-39$ & 33 & 96 & $129(31.1 \%)$ & Others & 24 & 23 & $47(11.3 \%)$ \\
\hline $40-49$ & 59 & 66 & $125(30.2 \%)$ & \multicolumn{4}{|c|}{ Number of visits to Jeju including this trip } \\
\hline 50 or above & 26 & 24 & $50(12.0 \%)$ & 1 & 49 & 163 & $212(51.1 \%)$ \\
\hline \multicolumn{4}{|c|}{ Monthly Income (million, Korean Won) } & 2 & 66 & 21 & $87(21.0 \%)$ \\
\hline Below 2 & 20 & 15 & $35(10.6 \%)$ & 3 & 35 & 6 & $41(9.9 \%)$ \\
\hline $2-4$ & 73 & 51 & $124(37.7 \%)$ & 4 or more & 61 & 14 & $75(18.1 \%)$ \\
\hline $4-6$ & 46 & 24 & $70(21.3 \%)$ & \multicolumn{4}{|c|}{ Length of stay } \\
\hline $6-8$ & 23 & 33 & $56(17.0 \%)$ & 1 2 days & 16 & 50 & $66(16.0 \%)$ \\
\hline Above 8 & 17 & 27 & $44(13.4 \%)$ & 3 days & 110 & 16 & $126(30.5 \%)$ \\
\hline & & & & 4 days & 39 & 75 & $114(27.6 \%)$ \\
\hline & & & & 5 or more & 44 & 63 & $107(25.9 \%)$ \\
\hline
\end{tabular}




\subsection{Instrument Development}

The instrument of this study consists of the five constructs: perceived value (PV), satisfaction (SAT), awareness of climate change (AW), moral responsibility for climate change (MR) and environmentally responsible behavior (ERB). Measurement items were adapted from the literature as follows.

Three PV items were adapted from [48,65], and three items of the SAT were derived from [66,67]. Perceived value can be analyzed with one-dimensional or multi-dimensional scales if there is no validity problem [68]. Thus, this study focuses on hedonic value to measure PV because the context of this study is nature-based tourism which attaches more value to the pleasure and comfort from natural environments than any interpersonal relationship or artificial products/services. Three AW items and three MR items were drawn from [52,54]. The AW can be defined as the perceived experience or knowledge of climate change while MR features the moral perception towards mitigating climate change. Finally, four items for ERB were adapted from [48] because these items fit this study context. Four ERBs are: accept the environment protection policy at the destination, help to maintain the environmental quality of the destination, sort my trash at the destination, and try not to disrupt the fauna and flora during my travel. We measured behavioral intention rather than measuring actual behavior.

All of these items were measured on a seven-point Likert scale ranging from strongly disagree (1) to strongly agree (7). The original survey was written in Korean, and then translated into Chinese. The translated Chinese version of the survey was then back translated to the original language, and corrections were made to address the differences between the original and Chinese versions. Two versions of the questionnaire were pre-tested and revised to ensure content validity.

Frequency analysis was used for characteristics of the samples, and a two-tailed independent t-test was performed to identify the differences in all constructs between Korean and Chinese. Finally, multiple linear regressions were used to examine the effects of PV, SAT, AW and MR on ERB as proposed objectives.

\section{Results}

\subsection{Reliability Test}

To identify the determinants of the ERB, an exploratory factor analysis (EFA) was conducted using a principal component method with Varimax rotation. We extracted four factors with standardized factor loadings above 0.697 and a total variance of $79.988 \%$ (see Table 2). For all constructs, the reliability analysis showed Cronbach's alpha values from 0.776 to 0.916 (see also Table 2). These measures indicate that reliability is supported for the constructs. Commonly, a Cronbach's alpha of 0.7 or above, factor loadings of 0.50 or above, and a total variance of at least $60 \%$ are acceptable as good indicators of reliability for the scales [69]. Results of test are described in Table 2.

Table 2. Results of reliability.

\begin{tabular}{|c|c|c|c|}
\hline Factor & Items & Estimate & Cronbach's $\alpha$ \\
\hline \multirow{3}{*}{ PV } & The quality of the eco-tourism exceeded my expectations & 0.819 & \multirow{3}{*}{0.859} \\
\hline & The quality of the natural environment exceeded my expectations & 0.913 & \\
\hline & The quality of outdoor activities exceeded my expectations & 0.781 & \\
\hline \multirow{3}{*}{ SAT } & Delighted about this travel & 0.863 & \multirow{3}{*}{0.916} \\
\hline & Overall satisfaction with this travel & 0.869 & \\
\hline & Satisfaction with this travel compared with expectation & 0.809 & \\
\hline \multirow{3}{*}{ AW } & Recently how much do you feel about climate change & 0.864 & \multirow{3}{*}{0.776} \\
\hline & Usually how much do you feel about climate change & 0.901 & \\
\hline & How well are you informed about climate change & 0.697 & \\
\hline \multirow{3}{*}{ MR } & To what extent do you have moral cocerns about climate change & 0.891 & \multirow{3}{*}{0.906} \\
\hline & $\begin{array}{l}\text { How much do you personally contribute to mitigating (reducing or } \\
\text { stopping) climate change }\end{array}$ & 0.918 & \\
\hline & How much do you personally support the climate change mitigation policy & 0.879 & \\
\hline
\end{tabular}




\subsection{Differences between Korean and Chinese Tourists}

There were significant differences in all variables by nationality (Table 3 ). AW was scored higher in Korean tourists $(t=7.510, p<0.001$, mean for Korean $=5.13$, mean for Chinese $=4.27)$, while Chinese tourists rated higher in all other variables: $\mathrm{PV}(t=-4.307, p<0.001$, mean for Korean $=5.43$, mean for Chinese $=5.84)$, SAT $(t=-3.013, p<0.01$, mean for Korean $=5.72$, mean for Chinese $=5.99)$, MR $(t=-3.277, p<0.01$, mean for Korean $=5.03$, mean for Chinese $=5.44)$, and ERB $(t=-4.091, p<0.001$, mean for Korean $=5.70$, mean for Chinese $=6.06$ ). In other words, Chinese tourists perceived more value and higher satisfaction about traveling in Jeju Island, and they had a higher level of moral responsibility for climate change and a higher level of environmentally responsible behavior intention at the destination. On the other hand, Korean tourists were more aware of climate change than the Chinese tourists, but their moral responsibility for climate change and environmental behavior intention scored lower than those of the Chinese tourists.

Table 3. Results of $t$-test.

\begin{tabular}{cccccc}
\hline \multirow{2}{*}{ Variables } & \multicolumn{2}{c}{ Group Mean } & \multirow{2}{*}{$\boldsymbol{t}$-Value } & \multirow{2}{*}{ Sig. } \\
\cline { 2 - 4 } & Korean & Chinese & Differences & & \\
\hline PV & $5.43(0.98)$ & $5.84(0.93)$ & -0.40 & -4.307 & 0.000 \\
SAT & $5.72(0.94)$ & $5.99(0.91)$ & -0.27 & -3.013 & 0.003 \\
AW & $5.13(1.10)$ & $4.27(1.23)$ & 0.86 & 7.510 & 0.000 \\
MR & $5.03(1.22)$ & $5.44(1.36)$ & -0.41 & -3.277 & 0.001 \\
ERB & $5.70(0.90)$ & $6.06(0.89)$ & -0.36 & -4.091 & 0.000 \\
\hline
\end{tabular}

Standard deviation is given in parenthesis.

\subsection{Relationships between $P V, S A T, A W, M R$ and $E R$}

In the first multiple regression model with aggregated data from the Korean and Chinese tourists, all entered independent variables, PV, SAT, and MR, with the exception of AW, significantly affected the environmentally responsible behavior intention (ERB) (see Table 4). The strongest predictor was PV $(\beta=0.273, t=4.858, p<0.001)$ followed by SAT $(\beta=0.265, t=4.733, p<0.001)$ and MR $(\beta=0.226, t=5.311, p<0.001)$. Next, separate multiple regression analyses were run for Korean and Chinese tourist groups. Results showed that there were significant differences in the determinants of ERB between Korean and Chinese groups (see Table 5). That is, the results presented that all four independent variables had significant positive effects on ERB among Korean tourists, while only tourist experience-related variables (i.e., PV and SAT) were significant in predicting ERB among Chinese tourists.

Table 4. Linear regression analysis.

\begin{tabular}{ccccc}
\hline Variable & B & Beta & $t$ & Sig. \\
\hline Constant & 1.958 & 0.273 & 7.313 & 0.000 \\
PV & 0.255 & 0.265 & 4.858 & 0.000 \\
SAT & 0.259 & 0.040 & 4.733 & 0.000 \\
AW & 0.029 & 0.226 & 0.972 & 0.332 \\
MR & 0.158 & 5.311 & 0.000 \\
\hline \multicolumn{5}{c}{ Model Summary: $\mathrm{R}^{2}=0.375$, adjusted R ${ }^{2}=0.396$, Durbin-Watson $=1.972$} \\
\hline \multicolumn{5}{c}{ Dependent variable: ERB. }
\end{tabular}

Among Korean tourists, the effects of PV $(t=2.496, p<0.05)$, SAT $(t=2.685, p<0.01)$, AW $(t=4.190$, $p<0.001)$ and MR $(t=5.337, p<0.001)$ on ERB were statistically significant, and those variables explained $39.6 \%$ of the total variance in ERB (see also Table 5). Meanwhile, only PV $(t=2.685, p<0.01$ ) 
and SAT $(t=2.685, p<0.01)$ had positive significant effects on ERB among Chinese tourist group. PV and SAT explained approximately $39.1 \%$ of the total variance in ERB. The strongest influence on ERB was MR ( $\beta=0.306)$, followed by AW ( $\beta=0.238)$, SAT $(\beta=0.196)$ and PV $(\beta=0.183)$, among Korean tourists, and SAT ( $\beta=0.346)$ was the strongest predictor of ERB, followed by PV ( $\beta=0.291)$, among Chinese tourists. The results of linear regression analyses are shown in Tables 3 and 4 .

Table 5. Linear regression analysis by groups.

\begin{tabular}{|c|c|c|c|c|c|}
\hline Group & Variable & B & Beta & $t$ & Sig. \\
\hline \multirow[t]{5}{*}{ Korean } & Constant & 1.568 & & 4.314 & 0.000 \\
\hline & PV & 0.168 & 0.183 & 2.496 & 0.013 \\
\hline & SAT & 0.188 & 0.196 & 2.685 & 0.008 \\
\hline & $\mathrm{AW}$ & 0.195 & 0.238 & 4.190 & 0.000 \\
\hline & MR & 0.227 & 0.306 & 5.337 & 0.000 \\
\hline \multicolumn{6}{|c|}{ Model Summary: $\mathrm{R}^{2}=0.406$, adjusted $\mathrm{R}^{2}=0.394$, Durbin-Watson $=1.954$} \\
\hline \multirow[t]{5}{*}{ Chinese } & Constant & 2.100 & & 5.651 & 0.000 \\
\hline & PV & 0.279 & 0.291 & 3.484 & 0.001 \\
\hline & SAT & 0.339 & 0.346 & 4.185 & 0.000 \\
\hline & $\mathrm{AW}$ & -0.030 & -0.041 & -0.673 & 0.502 \\
\hline & MR & 0.079 & 0.121 & 1.898 & 0.059 \\
\hline
\end{tabular}

Model Summary: $\mathrm{R}^{2}=0.403$, adjusted $\mathrm{R}^{2}=0.391$, Durbin-Watson $=1.907$

Dependent variable: ERB.

\section{Discussion}

Based on the present study's findings, four theoretical contributions are presented with relevant managerial suggestions.

First, this study's results show that while Korean tourists highly recognize the climate change compared to the Chinese, their level of moral responsibility toward climate change is relatively low in comparison. Also, the likelihood of Korean tourists' environmentally responsible behavior is less than that of the Chinese tourists. These findings imply that awareness of climate change might not be an influential factor in explaining environmentally responsible behavioral intention. This exploratory notion is supported by a subsequent multiple regression analysis. The regression analysis combining Korean and Chinese tourists reveals that three determinants-i.e., moral responsibility for climate change, perceived value, and satisfaction-are statistically significant in inducing the environmentally responsible behavior intention; however, awareness of climate change does not have an impact on the behavioral intention. This finding is consistent with previous literature, which stated that tourists are not likely to translate environmental awareness into voluntarily changing their behavior to reduce negative environmental consequences [56,57]. Meanwhile, as perceptions toward climate change are different depending on nationality [58], further investigation is necessary to discuss research findings, particularly in the context of nature-based tourism destinations which invite international tourists.

Second, two regression models with Korean and Chinese tourists show a clear divergence in influential factors of environmentally responsible behavior. This research finding shows that perceptions toward climate change (i.e., awareness and responsibility) have impacts on the environmentally responsible behavior intention among domestic Korean tourists, but not among Chinese tourists. This finding partially supports the Value-Belief-Norm theory [42], suggesting that tourists are likely to be engaged in environmentally responsible behavior when they are aware of the environmental issues and feel morally responsible for the issues. The explanation of this theory works, however, only for domestic Korean tourists and not for Chinese tourists, according to this study's findings. These divergent findings support the notion that climate change could still be a fairly vague term that can differ among individuals in different countries [58]. In addition, individuals may 
perceive that climate change would only occur in the future or affect others first [70]. For example, [5] found that only $12 \%$ of Americans thought that climate change would affect them or their families directly, while others believed climate change would have an impact outside their countries. Foreign tourists who travel overseas, contrary to domestic tourists, may not be motivated to behave in an environmentally responsible way just due to being aware of climate change or a feeling of moral responsibility for climate change when they travel outside of their home country. As such, resource managers should develop differentiated environmental campaigns that target different tourist groups. Messages or information designed to encourage tourists' environmentally responsible behavior would not be effective for international tourists if focusing only on increasing awareness and activation of a moral norm with regard to climate change. Since awareness and moral responsibility are powerful determinants of environmental behavioral intention among domestic tourists, such determinants could be utilized in fostering domestic tourist behavior when implementing the necessary policies or campaigns.

The third contribution from the findings in this research is that tourists-perceived value and satisfaction have impacts on environmentally responsible behavior intention among both Korean and Chinese tourists. The findings add explanations to the literature discussing the environment-related attitude-behavior (or behavioral intention) gaps. That is, in addition to or beyond environment-related motives such as moral responsibility, there are other influential factors such as experience-related motives in formulating environmentally responsible behavior among nature-based tourists. In this sense, this study's findings are supported by previous literature showing that tourist-perceived valuable experiences may result in additional support for natural resources conservation in a protected area [63]. The present study's findings are also consistent with the point of previous literature [56], which showed that there would be situational factors and other internal factors in motivating environmental behavior. The present study shows that both the domestic and international tourists who experience higher value and satisfaction would be more likely to engage in environmental behavior at tourist destinations. The findings on the relationships between tourists' experiences and environmental behavior are supported by previous literature on tourism $[10,12,60]$. A well-conserved and well-managed natural resource would create experiences that are attractive to tourists, which in turn will produce higher tourist satisfaction [60]. In understanding the linkage of resource conservation, tourists' experiences, and environmental behavior, Ramkissoon et al. [12] revealed that satisfaction with a place leads to greater environmentally responsible behavior in nature-based tourism destinations. Based on the previous literature and this study's findings, it is therefore important to focus on how to couple conservation and tourism benefits in nature-based tourism destinations. Nature-based tourism managers should make greater efforts to increase tourists' perceived value and satisfaction in relation to nature-based tourism activities that accompany environmentally responsible behavior. For example, interpretation programs can be used to foster experiential engagement and appreciation of esthetics, to increase tourist values and travel satisfaction, and to increase environmentally responsible behavior [71]. This could benefit tourism planners and resource managers who strive to achieve both environmental sustainability and maximize tourist satisfaction.

Fourth, as shown in the results, Korean tourists' environmentally responsible behavior intention is affected both by tourist perceptions toward climate change (i.e., awareness and responsibility) as well as tourists' experiences (i.e., perceived value and satisfaction). In this regard, tourism planners and resources managers could have choices when designing effective environmental programs and attractive tourism products targeting domestic Korean tourists: (1) climate change issues could be embedded in environmental campaigns or information for tourists that could result in inducing tourist engagement in environmental behavior; (2) planners and managers may make efforts toward increasing tourists' perceived value and satisfaction in association with providing nature-based recreational activities; and (3) informational, moral and high quality experiential approaches could be combined to foster environmentally responsible behavior among domestic tourists. 
Marketers and managers in nature-based tourism destinations need to see tourists as "partners" who voluntarily engage in environmentally responsible behavior rather than those whose adverse behavior should be controlled and limited by using regulations and laws [10]. In contrast to the pessimistic view about the role of personal benefits in inducing environmental awareness-when personal benefits are seen to be large and the perceived environmental impacts are seen to be small [1]—-the present study suggests that dual goals toward sustainable tourism-i.e., minimizing negative environmental impacts to host areas as well as providing a quality tourist experience-would be attainable.

\section{Conclusions}

Notwithstanding the theoretical and practical contributions towards better understanding the relationships between climate change, tourist experiences, and tourists' environmentally responsible behaviors, this study has limitations which researchers should consider when evaluating the study's findings. This study measured behavioral intentions rather than actual behavior. Accordingly, it is possible that there would be gaps between behavioral intention and actual behavior. To address this, researchers acknowledge that restrictions need to be placed on interpreting the determinants of behavioral intention. Also, this study utilized non-probability sampling, and this limits the ability to generalize the findings. Additionally, this research compared behavior models between domestic Korean and Chinese international tourists who travelled to Jeju Island in Korea, and thus it is recommend to apply this model with other nations and with tourist groups of different nationalities in future research. This paper is exploratory in nature and encourages the conduct of further in-depth studies with the aim of influencing tourists' environmentally responsible behavior in nature-based tourism destinations. In conclusion, emphasizing economic viability and environmental responsibility as joint goals of sustainable tourism development and management partnerships in natural heritage areas is deemed appropriate if the destinations provide tourists valuable experiences and encourage them to engage in environmentally responsible behavior while traveling.

Acknowledgments: This work was supported by a National Research Foundation of Korea Grant Founded by the Korea Government (NRF-2013S1A5B6043772).

Author Contributions: Ju Hyoung Han and Min Jae Lee participated in analyzing the data and writing up the manuscript. Min Jae Lee designed the study questionnaires and Yun-Seop Hwang conducted the surveys to collect the data and participated in revising the manuscript.

Conflicts of Interest: The authors declare no conflict of interest. The funding sponsor had no role in the design of the study; in the collection, analyses, or interpretation of data; in the writing of the manuscript, and in the decision to publish the results.

\section{Abbreviations}

The following abbreviations are used in this manuscript:

$\begin{array}{ll}\text { PV } & \text { Perceived Value } \\ \text { SAT } & \text { Satisfaction } \\ \text { AW } & \text { Awareness of Climate Change } \\ \text { MR } & \text { Moral Responsibility for Climate Change } \\ \text { ERB } & \text { Environmentally Responsible Behavior }\end{array}$

\section{References}

1. Becken, S. How tourists and tourism experts perceive climate change and carbon-offsetting schemes. J. Sustain. Tour. 2004, 12, 332-345. [CrossRef]

2. Whitmarsh, L. Behavioural responses to climate change: Asymmetry of intentions and impacts. J. Environ. Psychol. 2009, 29, 13-23. [CrossRef]

3. UNWTO. 1st Conference on Climate Change and Tourism. Available online: http://sdt.unwto.org/event/ 1st-conference-climate-change-and-tourism (accessed on 30 May 2016). 
4. Scott, D.; Amelung, B.; Becken, S.; Ceron, J.; Dubois, G.; Gössling, S.; Peeters, P.; Simpson, M. Climate Change and Tourism: Responding to Global Challenges; World Tourism Organization: Madrid, Spain, 2008; p. 230.

5. Leiserowitz, A. Climate change risk perception and policy preferences: The role of affect, imagery, and values. Clim. Change 2006, 77, 45-72. [CrossRef]

6. McKercher, B.; Prideaux, B.; Cheung, C.; Law, R. Achieving voluntary reductions in the carbon footprint of tourism and climate change. J. Sustain. Tour. 2010, 18, 297-317. [CrossRef]

7. Martín, M.G.B. Weather, climate and tourism: A geographical perspective. An. Tour. Res. 2005, 32, 571-591. [CrossRef]

8. Becken, S. The importance of climate and weather for tourism. In Land Environment E People Miscellaneous Publications; LEaP, Lincoln University: Canterbury, New Zealand, 2010.

9. Ballantyne, R.; Packer, J.; Falk, J. Visitors' learning for environmental sustainability: Testing short- and long-term impacts of wildlife tourism experiences using structural equation modelling. Tour. Manag. 2011, 32, 1243-1252. [CrossRef]

10. Lee, T.H.; Jan, F.H. The influence of recreation experience and environmental attitude on the environmentally responsible behavior of community-based tourists in taiwan. J. Sustain. Tour. 2015, 23, 1063-1094. [CrossRef]

11. Lee, T.H.; Jan, F.H.; Huang, G.W. The influence of recreation experiences on environmentally responsible behavior: The case of Liuqiu Island, Taiwan. J. Sustain. Tour. 2015, 23, 947-967. [CrossRef]

12. Ramkissoon, H.; Smith, L.D.G.; Weiler, B. Relationships between place attachment, place satisfaction and pro-environmental behaviour in an Australian national park. J. Sustain. Tour. 2013, 21, 434-457. [CrossRef]

13. Halpenny, E.A. Pro-environmental behaviours and park visitors: The effect of place attachment. J. Environ. Psychol. 2010, 30, 409-421. [CrossRef]

14. Duerden, M.D.; Witt, P.A. The impact of direct and indirect experiences on the development of environmental knowledge, attitudes, and behavior. J. Environ. Psychol. 2010, 30, 379-392. [CrossRef]

15. Ballantyne, R.; Packer, J.; Sutherland, L.A. Visitors' memories of wildlife tourism: Implications for the design of powerful interpretive experiences. Tour. Manag. 2011, 32, 770-779. [CrossRef]

16. Cabrini, L.; Simpson, M.; Scott, D.; Yunis, E.; Urosevic, Z.; Gutierrez, S.; Calvente, A. From Davos to Copenhagen and Beyond: Advancing Tourism's Response to Climate Change: Unwto Background Paper; World Tourism Organization: Madrid, Spain, 2009.

17. Morrison, C.; Pickering, C.M. Perceptions of climate change impacts, adaptation and limits to adaption in the Australian Alps: The ski-tourism industry and key stakeholders. J. Sustain. Tour. 2013, 21, 173-191. [CrossRef]

18. Gössling, S.; Scott, D.; Hall, C.M.; Ceron, J.P.; Dubois, G. Consumer behaviour and demand response of tourists to climate change. Ann. Tour. Res. 2012, 39, 36-58. [CrossRef]

19. Moore, W.R. The impact of climate change on Caribbean tourism demand. Curr. Issues Tour. 2010, 13, 495-505. [CrossRef]

20. Bigano, A.; Hamilton, J.M.; Tol, R.S.J. The impact of climate on holiday destination choice. Clim. Change 2006, 76, 389-406. [CrossRef]

21. Eugenio-Martin, J.L.; Campos-Soria, J.A. Climate in the region of origin and destination choice in outbound tourism demand. Tour. Manag. 2010, 31, 744-753. [CrossRef]

22. Amelung, B.; Nicholls, S.; Viner, D. Implications of global climate change for tourism flows and seasonality. J. Travel Res. 2007, 45, 285-296. [CrossRef]

23. Gössling, S.; Hall, C.M. Uncertainties in predicting tourist flows under scenarios of climate change. Clim. Change 2006, 79, 163-173. [CrossRef]

24. Perch-Nielsen, S.L. The vulnerability of beach tourism to climate change-an index approach. Clim. Change 2010, 100, 579-606. [CrossRef]

25. Elsasser, H.; Bürki, R. Climate change as a threat to tourism in the Alps. Clim. Res. 2002, 20, $253-257$. [CrossRef]

26. Tranos, E.; Davoudi, S. The regional impact of climate change on winter tourism in Europe. Tour. Plan. Dev. 2014, 11, 163-178. [CrossRef]

27. Marshall, N.A.; Marshall, P.A.; Abdulla, A.; Rouphael, T.; Ali, A. Preparing for climate change: Recognising its early impacts through the perceptions of dive tourists and dive operators in the Egyptian Red Sea. Curr. Issues Tour. 2011, 14, 507-518. [CrossRef] 
28. Zeppel, H. Climate change and tourism in the Great Barrier Reef Marine Park. Curr. Issues Tour. 2012, 15, 287-292. [CrossRef]

29. Scott, D.; Lemieux, C. Weather and climate information for tourism. Procedia Environ. Sci. 2010, 1, 146-183. [CrossRef]

30. Hamilton, J.M.; Maddison, D.J.; Tol, R.S.J. Climate change and international tourism: A simulation study. Glob. Environ. Change 2005, 15, 253-266. [CrossRef]

31. Klint, L.M.; Wong, E.; Jiang, M.; Delacy, T.; Harrison, D.; Dominey-Howes, D. Climate change adaptation in the Pacific Island tourism sector: Analysing the policy environment in Vanuatu. Curr. Issues Tour. 2012, 15, 247-274. [CrossRef]

32. Buzinde, C.N.; Manuel-Navarrete, D.; Yoo, E.E.; Morais, D. Tourists' perceptions in a climate of change: Eroding destinations. Ann. Tour. Res. 2010, 37, 333-354. [CrossRef]

33. Becken, S. Analysing international tourist flows to estimate energy use associated with air travel. J. Sustain. Tour. 2002, 10, 114-131. [CrossRef]

34. Gössling, S. Sustainable tourism development in developing countries: Some aspects of energy use. J. Sustain. Tour. 2000, 8, 410-425. [CrossRef]

35. Ponater, M.; Sausen, R.; Feneberg, B.; Roeckner, E. Climate effect of ozone changes caused by present and future air traffic. Clim. Dyn. 1999, 15, 631-642. [CrossRef]

36. Olsthoorn, X. Carbon dioxide emissions from international aviation: 1950-2050. J. Air Transp. Manag. 2001, 7, 87-93. [CrossRef]

37. Uyarra, M.C.; Côté, I.M.; Gill, J.A.; Tinch, R.R.T.; Viner, D.; Watkinson, A.R. Island-specific preferences of tourists for environmental features: Implications of climate change for tourism-dependent states. Environ. Conserv. 2005, 32, 11-19. [CrossRef]

38. Zehr, S.C. Public representations of scientific uncertainty about global climate change. Public Underst. Sci. 2000, 9, 85-103. [CrossRef]

39. Wilkinson, C.R. Global change and coral reefs: Impacts on reefs, economies and human cultures. Glob. Change Biol. 1996, 2, 547-558. [CrossRef]

40. West, J.M.; Salm, R.V. Resistance and resilience to coral bleaching: Implications for coral reef conservation and management. Conserv. Biol. 2003, 17, 956-967. [CrossRef]

41. Nicholls, R.J. Assessing erosion of sandy beaches due to sea-level rise. In Geological Society Engineering Geology Special Publication; Geological Society: London, UK, 1998; Volume 15, pp. 71-76.

42. Stern, P.C. New environmental theories: Toward a coherent theory of environmentally significant behavior. J. Soc. Issues 2000, 56, 407-424. [CrossRef]

43. Lee, T.H. How recreation involvement, place attachment and conservation commitment affect environmentally responsible behavior. J. Sustain. Tour. 2011, 19, 895-915. [CrossRef]

44. Stockdale, A.; Barker, A. Sustainability and the multifunctional landscape: An assessment of approaches to planning and management in the Cairngorms National Park. Land Use Policy 2009, 26, 479-492. [CrossRef]

45. Iwata, O. Attitudinal determinants of environmentally responsible behavior. Soc. Behav. Personal. Int. J. 2001, 29, 183-190. [CrossRef]

46. Thapa, B. The mediation effect of outdoor recreation participation on environmental attitude-behavior correspondence. J. Environ. Edu. 2010, 41, 133-150. [CrossRef]

47. Lee, T.H.; Jan, F.-H.; Yang, C.-C. Conceptualizing and measuring environmentally responsible behaviors from the perspective of community-based tourists. Tour. Manag. 2013, 36, 454-468. [CrossRef]

48. Chiu, Y.T.H.; Lee, W.I.; Chen, T.H. Environmentally responsible behavior in ecotourism: Antecedents and implications. Tour. Manag. 2014, 40, 321-329. [CrossRef]

49. Addison, P.F.E.; Koss, R.S.; O'Hara, T.D. Recreational use of a rocky intertidal reef in Victoria: Implications for ecological research and management. Australas. J. Environ. Manag. 2008, 15, 169-179. [CrossRef]

50. Davenport, J.; Davenport, J.L. The impact of tourism and personal leisure transport on coastal environments: A review. Estuar. Coast. Shelf Sci. 2006, 67, 280-292. [CrossRef]

51. Wikipedia. Climate Change. Available online: https://en.wikipedia.org/wiki/Climate_change (accessed on 30 May 2016).

52. Aitken, C.; Chapman, R.; McClure, J. Climate change, powerlessness and the commons dilemma: Assessing New Zealanders' preparedness to act. Glob. Environ. Change 2011, 21, 752-760. [CrossRef] 
53. Spence, A.; Poortinga, W.; Butler, C.; Pidgeon, N.F. Perceptions of climate change and willingness to save energy related to flood experience. Nat. Clim. Change 2011, 1, 46-49. [CrossRef]

54. Bostrom, A.; O'Connor, R.E.; Böhm, G.; Hanss, D.; Bodi, O.; Ekström, F.; Halder, P.; Jeschke, S.; Mack, B.; $\mathrm{Qu}, \mathrm{M}$; et al. Causal thinking and support for climate change policies: International survey findings. Glob. Environ. Change 2012, 22, 210-222. [CrossRef]

55. Van Riper, C.J.; Kyle, G.T. Understanding the internal processes of behavioral engagement in a national park: A latent variable path analysis of the value-belief-norm theory. J. Environ. Psychol. 2014, 38, 288-297. [CrossRef]

56. Kollmuss, A.; Agyeman, J. Mind the gap: Why do people act environmentally and what are the barriers to pro-environmental behaviour. Environ. Edu. Res. 2002, 8, 239-260. [CrossRef]

57. Kempton, W.; Boster, J.S.; Hartley, J.A. Environmental Values in American Culture; MIT Press: Cambrige, MA, USA, 1995.

58. Capstick, S.; Whitmarsh, L.; Poortinga, W.; Pidgeon, N.; Upham, P. International trends in public perceptions of climate change over the past quarter century. Wiley Interdiscip. Rev. Clim. Chang. 2015, 6, 435. [CrossRef]

59. Brechin, S.R. 10 public opinion: A cross-national view. In Routledge Handbook of Climate Change and Society; Routledge Press: New York, NY, USA, 2010; p. 179.

60. Coghlan, A. Linking natural resource management to tourist satisfaction: A study of Australia's Great Barrier Reef. J. Sustain. Tour. 2012, 20, 41-58. [CrossRef]

61. Petrick, J.F. The roles of quality, value, and satisfaction in predicting cruise passengers' behavioral intentions. J. Travel Res. 2004, 42, 397-407. [CrossRef]

62. Mano, H.; Oliver, R.L. Assessing the dimensionality and structure of the consumption experience: Evaluation, feeling, and satisfaction. J. Consum. Res. 1993, 20, 451-466. [CrossRef]

63. McCool, S. Managing for visitor experiences in protected areas: Promising opportunities and fundamental challenges. Parks 2006, 16, 3-10.

64. Jeju Tourism Statistics. Available online: http://www.ijto.or.kr (accessed on 30 May 2016).

65. Calver, S.J.; Page, S.J. Enlightened hedonism: Exploring the relationship of service value, visitor knowledge and interest, to visitor enjoyment at heritage attractions. Tour. Manag. 2013, 39, 23-36. [CrossRef]

66. Lee, C.K.; Yoon, Y.S.; Lee, S.K. Investigating the relationships among perceived value, satisfaction, and recommendations: The case of the Korean DMZ. Tour. Manag. 2007, 28, 204-214. [CrossRef]

67. Žabkar, V.; Brenčič, M.M.; Dmitrović, T. Modelling perceived quality, visitor satisfaction and behavioural intentions at the destination level. Tour. Manag. 2010, 31, 537-546. [CrossRef]

68. Chen, C.F.; Chen, F.S. Experience quality, perceived value, satisfaction and behavioral intentions for heritage tourists. Tour. Manag. 2010, 31, 29-35. [CrossRef]

69. Hair, J.F.; Black, J.W.; Babin, B.J.; Anderson, R.E. Multivariate Data Analysis: A Global Perspective, 7th ed.; Pearson: Essex, UK, 2010.

70. Patchen, M. Public Attitudes and Behaviour about Climate Change: What Shapes Them and How to Influence Them?; Purdue Climate Change Research Center Outreach: West Lafayette, IN, USA, 2006.

71. Xu, H.; Cui, Q.; Ballantyne, R.; Packer, J. Effective environmental interpretation at Chinese natural attractions: The need for an aesthetic approach. J. Sustain. Tour. 2013, 21, 117-133. [CrossRef]

(C) 2016 by the authors; licensee MDPI, Basel, Switzerland. This article is an open access article distributed under the terms and conditions of the Creative Commons Attribution (CC-BY) license (http://creativecommons.org/licenses/by/4.0/). 